\title{
"A comparative literature review survey of employee HIV and AIDS-related corporate social responsibility (CSR) practices in small, micro and medium enterprises (SMMEs) in Zimbabwe and South Africa"
}

\begin{tabular}{|c|c|}
\hline AUTHORS & $\begin{array}{l}\text { Tendai Makwara (D https://orcid.org/0000-0002-4132-7224 } \\
\text { Masiwa Mutambara } \\
\text { Sihle W. Magagula-Hlatjwako (D https://orcid.org/0000-0001-9161-6043 }\end{array}$ \\
\hline ARTICLE INFO & $\begin{array}{l}\text { Tendai Makwara, Masiwa Mutambara and Sihle W. Magagula-Hlatjwako (2019). } \\
\text { A comparative literature review survey of employee HIV and AIDS-related } \\
\text { corporate social responsibility (CSR) practices in small, micro and medium } \\
\text { enterprises (SMMEs) in Zimbabwe and South Africa. Problems and Perspectives } \\
\text { in Management, 17(1), 339-347. doi:10.21511/ppm.17(1).2019.29 }\end{array}$ \\
\hline DOI & http://dx.doi.org/10.21511/ppm.17(1).2019.29 \\
\hline RELEASED ON & Monday, 01 April 2019 \\
\hline RECEIVED ON & Thursday, 07 February 2019 \\
\hline ACCEPTED ON & Tuesday, 26 February 2019 \\
\hline LICENSE & $\begin{array}{l}(c) \text { EY } \\
\text { This work is licensed under a Creative Commons Attribution } 4.0 \text { International } \\
\text { License }\end{array}$ \\
\hline JOURNAL & "Problems and Perspectives in Management" \\
\hline ISSN PRINT & $1727-7051$ \\
\hline ISSN ONLINE & $1810-5467$ \\
\hline PUBLISHER & LLC "Consulting Publishing Company "Business Perspectives" \\
\hline FOUNDER & LLC "Consulting Publishing Company "Business Perspectives" \\
\hline
\end{tabular}

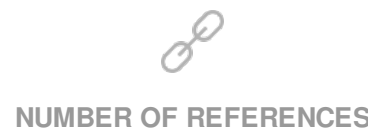

50
NUMBER OF FIGURES

0
NUMBER OF TABLES

0

(C) The author(s) 2023. This publication is an open access article. 


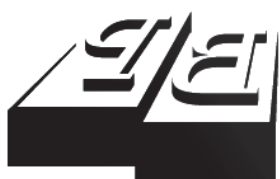

BUSINESS PERSPECTIVES

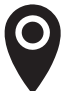

LLC "CPC "Business Perspectives" Hryhorii Skovoroda lane, 10, Sumy, 40022, Ukraine

www.businessperspectives.org

Received on: $7^{\text {th }}$ of February, 2019 Accepted on: $26^{\text {th }}$ of February, 2019

(c) Tendai Makwara, Sihle W. Magagula-Hlatjwako, Masiwa Mutambara, 2019

Tendai Makwara, Doctoral Student, Boston City Campus \& Business College, Cape Town, South Africa.

Sihle W. Magagula-Hlatjwako, Doctoral Student, Boston City Campus \& Business College, Johannesburg, South Africa.

Masiwa Mutambara, Master, St Francis Adult Education Centre, South Africa.
Tendai Makwara (South Africa), Sihle W. Magagula-Hlatjwako (South Africa),

Masiwa Mutambara (South Africa)

\begin{abstract}
This article reviews employee HIV and AIDS-related corporate social responsibility (CSR) practices by small business in Zimbabwe and South Africa. The article aims to present a comparative snapshot of how SMMEs are responding to the epidemic as a basis for developing a CSR framework that could be implemented by SMMEs in both countries. The article applies an exploratory literature review methodology to extract data from secondary sources. Research findings show that HIV and AIDS-related CSR in Zimbabwe appear disengaged from the direct influence of corporate business, the opposite of what South African SMMEs experience. In South Africa, SMME CSR practices experience pressure from large firms. However, differences in economic status between the two countries show no effect on the CSR behaviors of SMMEs in both countries when compared with each other. In both countries, findings reveal that SMMEs hardly establish HIV and AIDS policies and therefore rely on informal CSR practices to assist employees to deal with the pandemic in the workplace. Thus, the article submits that while HIV and AIDS practices are not formalized in both countries, SMMEs fulfil their epidemic-related CSR obligations towards employees' corresponding with their smallness. In conclusion, the study recommends an empirical examination of the research question to establish a grounded recommendation for the development of a SMMEs CSR framework that could be implemented by SMMEs in both countries.
\end{abstract}

Keywords

JEL Classification corporate social responsibility, employees, HIV and AIDS, large business, SMMEs

\section{INTRODUCTION AND RESEARCH FOCUS}

Zimbabwe and South Africa are two Southern African countries bedevilled with the HIV and AIDS epidemic to greater proportions. According to UNAIDS statistics, 1.3 million Zimbabweans and 6.2-7 million South Africans are living with HIV (AVERT, 2019). While there are commendable, government efforts to arrest the epidemic, debates still rage on the contribution from the business sector in confronting the epidemic. Despite the well-known economic hardships in Zimbabwe, government and donor sponsored HIV and AIDS programs have been kept alive, saving the lives of many citizens (Chevo \& Bhatasara, 2012; Fleshman, 2006). Likewise, the South African government runs the world's largest antiretroviral program to promote access to medication for those living with the epidemic (AVERT, 2019). These highlighted posi- 
tive steps in Zimbabwe and South Africa, however, do not mask the implementation challenges inherent in the programs they run.

In contrast to the actions of the respective governments, the business community's response to the epidemic is rather disappointing and tragic. According to Rosen, Feely, Connelly, and Simon (2007, p. S42): "the appropriate role of the private sector in fighting the epidemic remains an unanswered question in most countries" and this is no less apparent in Zimbabwe and South Africa. Makwara $(2015$, p. 9) further contends that the response pattern of business to HIV intervention is still an evolving process with full commitment yet to be realized. Dickinson (2004) poses a question 'Corporate South Africa's response to HIV and AIDS: Why so slow?' Arguably, the business community, including SMMEs, still regard the issue of HIV and AIDS as a public health concern, which lies in the government domain and civil society (Davids, Weihs, Tunzi, \& Tassiopoulos, 2017, p. 29). Thus, if they are to take interest in addressing the epidemic, it is motivated purely by aims to meet business case ends (Douglas \& Sutherland, 2009). Evidence of this bias can be drawn from abundant literature that justifies HIV and AIDS social responsibility emphasizing its costs to business and reputational benefits (Deane, Stevano, \& Johnston, 2018) than altruistic motivations. Additionally, few firms have instituted HIV and AIDS policies in the workplace to show commitment to addressing the epidemic, and even among those that do have many are thriving on 'talking the talk' rather than 'walking the talk'. Based on these observations, one could conclude that the business community still needs to prop up its attention to the epidemic.

Pursuant to exploring how business is responding to the epidemic, albeit at such a lethargic pace, this study limits its interest to the actions of SMMEs in Zimbabwe and South Africa towards arresting the epidemic in the workplace. The research objective is to develop a comparative overview of how SMMEs are responding to the epidemic as a basis for developing a framework that could be implemented by SMMEs in both countries. Additionally, the study frames a generalized understanding of SMMEs' HIV and AIDS related social responsibility in Zimbabwe and South Africa, and thus contributes to a growing body of knowledge on SMME and their context driven CSR practices in general and specifically towards HIV and AIDS.

\section{LITERATURE REVIEW}

\subsection{Employee related HIV and AIDS practices by SMMEs in Zimbabwe}

While it is a global truth that more has been done by large businesses than SMMEs in terms of initiating workplace measures to arrest the epidemic, response patterns experienced in Zimbabwe can be explained on two fronts: 1) the general malaise associated with 'smallness' and 2) the worsening economic climate in the country. Emphasizing the second aspect, Kaseke (2009, p. 18) states that "under this environment, it makes little sense for employers to provide funds for workplace HIV and AIDS programs when their businesses are on the brink of collapse". Although this observation applies to all firm sizes, its implication resonates more in SMMEs who experience financial difficulties as part of their daily operational challenges. In respect of the challenges of 'smallness',
SMMEs found it difficult to undertake social responsibility practices that require investment and specialized knowledge such as HIV/AIDS because of lack of technical skills (ILO, Ministry of Small and Medium Enterprises Development, 2006) and resource limitations.

Related empirical studies also conducted in the country suggest that SMMEs rely on survivalist CSR techniques to meet the HIV/AIDS challenges in the workplace. A Government of Zimbabwe and International Labor Organization (ILO) (2006) study investigating the impact of HIV and AIDS on SMME sector found that there was a general lack of workplace HIV and AIDS programs in the SMME sector, as $67 \%$ of them did not have anything in place. This fact was later confirmed by Vinga (2017) who also reported that SMMEs employees rely on electronic and print media for HIV/AIDS information rather than from their workplace. Kaniki (2003) reports findings of a 
case study looking at the perceptions of employers about HIV and AIDS in SMMEs in Harare, which focused on the salons, cafés and travel agencies. The case study reveals that in salons, the employers tended to disown financial liability for employee treatment, with $90 \%$ of those interviewed in the sector urging employees to pay their own health bills. In the travel agency sector, despite $40 \%$ of respondents claiming to contribute towards meeting treatment costs, to evade the HIV/AIDS financial burden, SMMEs opted to dismiss employees and offer short non-renewable contracts. More favorable trends were, however, observed in the cafés sector, where $50 \%$ of the respondents claimed to extend interest free 'health loans' to foot their medical bills among other interventions.

In making interpretation to the findings in Kaniki (2003), attention has to be paid to the fact that the study was conducted during the early years of the decade of economic meltdown spanning 1997-2008 before the total collapse of the economy. Notable development in the intervening years include onset of hyperinflationary trends, reduced life expectancy, declining economic growth, loss of local currency and later dollarization of the economy (Makina, 2010). Chagonda (2016) assert that as the formal industry shrank because of tough economic conditions, the informal economy burgeoned, possibly because formal SMMEs abandoned their formal structures to position themselves to the new climate. If this position is correct, and alluding to developments that are even more recent when the economy has further declined worse off, the first question is, what chance is there that SMMEs in the present-day Zimbabwe can pay attention to the epidemic? On the other hand, the second question is, does this tough economic environment actually present an opportunity for SMME to adopt CSR practices in pursuit of reputation benefits?

Responding to the first question, CSR theory seems mute about how CSR manifests in worse economic climates as currently experienced in Zimbabwe, or if economic conditions have any express links with CSR behaviors at any stage. Thus, by implication, being socially responsible is assumed to be immune from prevailing economic conditions, or at least it points to its moral nature. Hence, theoretically, SMMEs in Zimbabwe are able to adopt CSR practices in the workplace to combat the epidemic. While expecting SMMEs to initiate programs such as provision of antiretroviral drugs, subsiding for medical expense and HIV and AIDS testing and counselling services is farfetched given their current operational challenges, active engagement with utilising external HIV/ AIDS services, as will be later argued, is possible. Note is taken of a findings in an International Labor Organization and Ministry of Small and Medium Enterprises Development (2006, p. 25) report suggesting that few firms active towards HIV and AIDS provided peer education, treatment, care and support, voluntary counselling and testing among other services. Yet, in the main, the same study affirms that most SMMEs do not have HIV and AIDS policies in the workplace.

Turning to the second question, results of a recent academic study investigating CSR practices in Zimbabwe (Manuere, 2016) reveal interesting findings in relation to the conception of CSR among SMMEs in Zimbabwe, among which is that SMMEs do not share a common understanding of CSR, each defines according to what they do. Additionally, they (SMMEs) see no economic value from engaging in CSR, suggesting that the business case motivation plays a lesser role in persuading the firms to adopt CSR practices. Furthermore, contrary to other empirical findings alleging that SMMEs CSR is biased towards employees (see Demuijnck \& Ngnodjom, 2012; Coppa \& Sriramesh, 2013), Manuere (2016) finds that SMMEs donate more to charity $(70 \%)$ than addressing employee welfare $(10 \%)$. These findings, in the authors' view, are consistent with an SMME environment that has become informal (no employees or very few) such that employee welfare is no longer a formal business concern and donations are warranted to support other more pressing social problems such as hunger and poverty, thus suggesting a possible impact of the economic environment on SMMEs CSR behavior. As a matter of fact, the cogency of these observations fall squarely within Amaeshi, Adegbite, Ogbechie et al. (2016, p. 21) who assert, despite the challenges of the contaminating context within which SMMEs in Africa operate, that there is an innate commitment to address their social responsibility, however limited this might be. 
Results of another International Labor Organization (2007, pp. 17-18) SMME survey further highlight other innovative approaches firms are using to cope with the challenges of the epidemic in the workplace. In one featured SMME, the owner solicited the help of the partner to take over duties of running the business, while she recovered from the epidemic related illness at home. Another entrepreneur reported forming a supporting group, with another HIV and AIDS volunteer to bring educational pamphlets from outside sources to share with others in the workplace. It is apparent that these CSR related activities rely on external resources and social goodwill requiring no internal investment, suggesting that SMMEs lack adequate resources to pursue firm-determined intervention approaches.

In conclusion, evidence suggest that most SMMEs in Zimbabwe do not have HIV and AIDS policies in place and practice survivalist types of CSR to assist employees deal with the epidemic. Employees rely on public external sources to access HIV and AIDS information. While the absence of HIV and policies and the minimal interventions may generally be interpreted to mean SMME perceived no benefit of such programmes (see ILO, Ministry of Small and Medium Enterprises Development, 2006 , p. 26), such a view is probably too simplistic about SMMEs trading in environment with bad economic conditions militating against normal business practices.

\subsection{Employee related HIV and AIDS practices by SMMEs in South Africa}

In South Africa a perception exists that SMMEs HIV and AIDS CSR practices in the workplace are under-researched (Enslin, 2007, p. 6), although notable literature has come to the fore (Steenkamp, Von der Marwitz, Baasner-Weihs, \& Pietersen, 2015; George \& Quinlan, 2009; Connelly \& Rosen, 2006) among others over the years. Notably, among such emerging studies, very few have focused on HIV and AIDS CSR practices in SMMEs beyond the conventional limits set by definitions borrowed from large business CSR to allow for differing interpretations suited to the size, nature, and capabilities of SMMEs. As such, findings that most SMMEs have no workplace HIV and AIDS policies
(Simbayi, 2007) nor do not offer HIV and AIDS testing services (Connelly \& Rosen, 2006) though valid and uncontested have become commonplace in literature. This is because CSR research in relation to HIV and AIDS in the workplace has become so endowed in searching for such abstract HIV and AIDS policies that salient practice stemming from the informal nature of SMMEs has been underappreciated. For example, social practices such as home visits by owner managers to see their sick employees or simple phone calls to check on their plight or to remind them of their scheduled hospital visits to collect antiretroviral treatment (ARVs) are rarely regarded as 'best practices', despite these practices having the effect of creating a caring workplace environment as an HIV and AIDS policy. Importantly, these CSR practices appertain the informal nature of SMMEs.

It goes without saying that, post 1994, the SMME CSR agenda in South Africa was focused on large business through legislative policies that also had the effect of pushing these large firms to the forefront of both theoretical and practical significance in CSR discourse. This has further impaired the partiality in appreciating CSR developments in the SMME sector. Thus, it is not surprising that CSR literature in South Africa is flooded with comparative statements between how much SMMEs' CSR towards HIV and AIDS in the workplace lags behind that of corporates (Tanga, Gutura, \& Shava, 2016, p. 229; Dickinson, 2004), while silent on the 'foreignness' of the measuring variables (such as formal HIV and AIDS policy) to SMMEs. Actually, some SMMEs do not know what an HIV and AIDS policy would entail or why it might be required (Stein, 2001, p. 16). To amplify the comparative bias, corporate-led HIV and AIDS programs and toolkits designed by others are recommended to SMMEs (see ILO, 2006, p. 26 - A handbook for small business associations and service providers), irrespective of whether such programs or toolkits fit the nature of each of the heterogeneous characters of SMMEs. Not to be outdone, government agencies (see Small Enterprise Development Agency 2015/2016 Annual Report) also volunteer to offer and arrange ad hoc HIV and AIDS support services to SMMEs. As a result, an overall picture emerges suggesting that SMMEs have no CSR impetus and skills to respond to the epidemic without propping up from large firms and government. 
Stemming from the above discussion, it is presumed SMMEs in South Africa are constrained from creating their own CSR policies by an assumption that they are always ready to participate in the existing ones (SA-German Chamber, CSR report as cited in GIZ, 2013, p. 192). This perception construes SMMEs as mere ready recipients of 'best practices' from large firms, thereby ignoring the fact such interventions may not be suited to the informal nature of SMMEs' CSR. Roy, Vyas, and Jain (2013, p. 13) contend ignoring SMMEs in CSR discourse also emerges from the extraordinary use of large business as the domain of CSR research and a sense that SMMEs are "little big companies" (Tilley, 2000) to whom large business practices will 'fit' if scaled down. The authors (Roy, Vyas, \& Jain, 2013) further state that SMMEs, through their less formal and looser control systems, naturally strive to create a good spirit in the workplace in the same manner as human resource practices (such having an HIV and AIDS policy) in large firm aim to create. In agreement, other authors (Gellert \& de Graaf, 2012, p. 354) indicate SMMEs make less use of formal instruments and strategies to implement CSR than bigger organizations, though this does not mean they do less. For that reason, the assessment parameters of what they are able and expected to do towards HIV and AIDS in the workplace must acknowledge these realities. The claim here has less to do with justifying the paucity of SMMEs CSR practices in view of the largeness of the HIV and AIDS problem in the workplace than to restate that CSR is a contextual practice. Thus, what is represented as HIV and AIDS 'best practices' (such as an HIV and AIDS policy) in large firms may represent worst experiences in SMMEs, as a result, they may disregard them, and uphold 'best practices' defined by who they are.

Contrary to scepticism attached to the CSR, behavior of SMMEs towards the epidemic extant evidence suggests that small firms do know and practice CSR towards the epidemic. This evidence emerges from studies that have departed from the spectrum of looking for HIV and AIDS policies in SMMEs as indicators of CSR. Duarte and Houlihan (2010) investigated HIV and AIDS interventions among SMMEs in Limpopo and listed assisting employees with funeral costs by employers as part of SMME CSR in relation to HIV and
AIDS. Similarly, Mapungwana (2014), in a study of young women workers' experiences of the HIV and AIDS response in SMMEs in KwaZulu Natal, found that SMMEs provide transport to funeral, keep vacancies open until employees sick with HIV/AIDS-related illness recovered, and allowed employees time to visit health centres to collect their medication as part of their HIV and AIDS CSR workplace practices. Notably, these interventions extended by SMMEs to employee fall within a portfolio of responsible recommendations as stated in Simbayi (2007), a study in the security and legal services sector. However, Mapungwana (2014) also found that SMMEs did not provide HIV and AIDS educational resources and employees relied on external public sources for information, an observation also reported in Chetty (2008, p. 158), a study also carried out in KwaZulu Natal. Additional findings in Chetty (2008, p. 158) state that most SMMEs subsidize staff members' medical aid (62.6\%) and offer their employees membership to a subsidised provident or pension fund (71.6\%).

In another research study, Bowen, Edwards, Simbayi, and Cattell (2013, pp. 20-21) investigated interventions by construction firms in the Western Cape and found that SMMEs facilitate employee medical treatment, provide transportation to medical centres, supply antiretroviral treatments (ARV's) for 3 months to infected employees (medium firms), as well as liaised with non-government organizations and clinics as part of their HIV and AIDS CSR initiatives. It is further reported that SMMEs employees prefer to go to the state hospitals than use in-house facilities (Bowen et al., 2013, p. 24), a finding that indicates either the perceived successful implementation of the HIV and AIDS program by the government or the inhospitable nature of SMME workplace in the eyes of the employees. In Davids, Weihs, Tunzi, and Tassiopoulos (2017), trends in the tourism alternate between having no HIV and AIDS policy to other SMMEs who provide antiretroviral support in and out of the workplace, facilitate counselling and provide peer education. Presumably, HIV and AIDS policies are present in relatively stable medium enterprises, because, as noted in the study, many small firms do regard such policies as too complex and associated services expensive. Complementary to these studies, Wilkins 
(1999) investigated the informal sector and found that such kind of small business did not have any CSR initiatives towards the epidemic.

In conclusion, literature in South Africa exhibits a comparative narrative between small business and large business to the extent SMMEs 'copy' or endeavor to adopt HIV and AIDS CSR practices in corporate South Africa. However, literature also reveals SMMEs are reliant on their own small scale and altruistic initiatives to improve employee welfare in the workplace. Thus, while they may be aware or feel pressure to enact HIV/AIDS policies or provide medical resources to employees like large business, SMMEs do not seem convinced HIV and AIDS is a special concern among the multitude of social problems they tackle in society.

\section{METHODOLOGY}

The research objective is to present a snapshot of the state of HIV and AIDS-related CSR in SMMEs found in Zimbabwe and South Africa. As such, an exploratory literature review approach was used with careful selection of literature that would credibly represent the status of CSR development in this sector across the two countries. Data sources consulted include institutional research and policy publications, research articles from academic sites such as Google Scholar, EBSCOhost, and the general Google platform.

\subsection{Theoretical framework}

This literature review study uses the concept of corporate social responsibility as its theory of study. CSR theory suggest firms commit to improving the wellbeing of society (Kotler \& Lee, 2005) arising from a belief that they (firms) have a moral and ethical duty to serve society (Maignan \& Ferrell, 2004). Formally defined, McWilliams, Siegel, and Wright (2006) state that CSR refer to "actions that appear to further some social good beyond the interest of the firm and that which is required by law". Works by Carroll (1999) conceptualize CSR as a form of business compliance to role expectations of shareholders, society and regulatory environments. Important to this study, while Birch and Moon (2011, p. 19) state "there is no single formula or template for
CSR worldwide", we understand this to mean at the firm level as well, such that differences between large business and SMMEs practices are acknowledged. Largely, business social practices underscore organizational commitment to solving social issues, such as HIV and AIDS for reasons that may or may not bear direct benefits to the business, but are important to other stakeholders such as employees, community, customers and government. Based on this premise, we postulate that SMMEs have to pay attention to HIV and AIDS if not for preserving their own market, then at least for safeguarding the lives of their employees and communities.

Furthermore, CSR theory also posits that public prejudice about CSR practices has been skewed towards large companies than SMMEs (Jenkins, 2006), perhaps because the concept of CSR is born in the large business domain. As such, SMME CSR tends to be low key, giving rise to a perception that they do not practice CSR (Fassin, 2008). Importantly, SMMEs' CSR practices are determined and shaped from the owner-managers' personal and moral convictions (Jamali, Zanhour, \& Keshishiani, 2009) and their employees (Rambe, 2018). In line with this reasoning, Jenkins (2006, p.6) observed that "the motivational pressures that may engage SMMEs in CSR are not the same as for large companies". Thus, while CSR in SMMEs may degenerate into being a conduit for expressing owner-manager's own cultural and ethical values towards society, CSR in large business, as shaped by formal policy, may be a peculiar marketing gimmick (Taghian et al., 2015), among other tasks. Accordingly, leveraging CSR in SMMEs solely as a business strategy is wholly inappropriate, because its purpose goes beyond the interests of the firm, and are possibly overshadowed by owner manager and employee relational interests. It has also been observed that the informal nature of SMMEs makes them highly flexible and adaptable to prevailing local community issues than would be possible with large businesses (Jenkins, 2006). Baumann-Pauly, Wickert, Spence, and Scherer (2013) further state that CSR practices in SMMEs derive from daily business conduct and are characterized by high employee participation in shaping up the agenda. In Demuijnck and Ngnodjom (2012), in a research conducted on Cameroonian SMEs, it was found 
that immediate CSR concern of the owner-mangers was security of the employees - "in a broad sense - access to health care of the employees and their families". On the basis of these theoretical viewpoints, one can contend that Zimbabwe and South Africa where HIV and AIDS threaten the firm survival, the owner and employees, SMMEs are possibly altering the scope of their internally focused CSR practices to focus on HIV and AIDS.
In this paper, theoretical conception of an SMME in both countries is that it is anything from a street vendor to enterprises employing less than 200 people (Tustin, 2015, p. 79). SMMEs are small entities, which are independently owned, managed by individuals, lack a national presence due to the size of their operations and workforce, and are heavily dependent on internal sources of capital to finance growth and expansion.

\section{DISCUSSION AND CONCLUSION}

Literature evidence from both Zimbabwe and South Africa shows that SMMEs experience a variety of operational, challenges from financial, knowledge and impetus to design formalized responses to the HIV and AIDS. Importantly, the concept of HIV and AIDS policy as signature of social responsibility runs parallel to the nature and aspirations of SMMEs who rely on informal and innovative approaches to assist employee to deal with the epidemic. Notwithstanding the foreign nature of such policies and cost implications, SMMEs have shown that they are capable of integrating big business oriented and HIV and AIDS policy based CSR practices with their own informal nature.

Literature from Zimbabwe intimate that SMMEs in that country are disengaged from large business influences, as well as institutional support as compared to SMME experiences in South Africa. The authors believe large business in Zimbabwe is constrained by the effects of a bad economy from extending their CSR influences to SMMEs. This is necessarily so because they may not be CSR compliant on their own account and they lack resources to support SMMEs. In contrast, corporate South Africa boasts a better economy and face a regulated CSR environment that forces them to support SMMEs.

In conclusion, this article has reviewed SMME HIV and AIDS-related CSR in Zimbabwe and South Africa. Findings suggest despite differences in Zimbabwean and South African economies and the role of large business in framing the CSR environment, SMMEs in both countries fulfil their CSR obligations through informal ways corresponding with their small business nature. As this article is based on literature reviews, an empirical examination of the research question to establish a grounded recommendation for the development of a SMMEs CSR framework that could be implemented by SMMEs in both countries is recommended.

\section{REFERENCES}

1. Amaeshi, K. et al. (2016). Corporate Social Responsibility in SMEs: a shift from philanthropy to institutional works. Journal of business Ethics, 138(2), 385-400. Retrieved from https://link. springer.com/article/10.1007/ s10551-015-2633-1

2. AVERT (2019). HIV AND AIDS IN SOUTH AFRICA. Retrieved from https://www.avert.org/ professionals/hiv-around-world/ sub-saharan-africa/south-africa (accessed on January 23, 2019).

3. Baumann-Pauly, D., Wickert, C., Spence, L., \& Scherer, A. (2013).
Organizing corporate social responsibility in small and large firms: Size matters. Journal of Business Ethics, 115(4), 693-705. Retrieved from https://link. springer.com/article/10.1007/ s10551-013-1827-7

4. Birch, D., \& Moon, J. (2011). Corporate social responsibility in Asia. Journal of Corporate Citizenship, 13, 18-23.

5. Bowen, P., Edwards, P., Simbayi, L., \& Cattell, K. (2013). HIV/AIDS interventions by construction firms in the Western Cape, South Africa: A thematic analysis of qualitative survey data. International Journal of Construction Management, 13(4), 11-33. https://doi.org/10.1080/156 23599.2013.10878227

6. Carroll, A. (1999). Corporate social responsibility: Evolution of a definitional construct. Business \& society, 38(3), 268295. Retrieved from https:// www.researchgate.net/publication/282441223_Corporate_social_responsibility_Evolution_ of_a_definitional_construct

7. Carroll, A. (2009, January). A look at the future of business ethics. Athens Banner-Herald. 
8. Chagonda, T. (2016). The other face of the Zimbabwean crisis: The black market and dealers during Zimbabwe's decade of economic meltdown, 2000-2008. Review of African Political Economy, 43(147), 131-141. https://doi.org/10.1080/0 3056244.2015.1048793

9. Chetty, S. (2008). Social Responsibility among Small and Medium Enterprises in KwazuluNatal (Doctoral dissertation University of KwaZulu-Natal).

10. Chevo, T., \& Bhatasara, S. (2012). HIV and AIDS programmes in Zimbabwe: implications for the health system. ISRN Immunology. http://dx.doi. org/10.5402/2012/609128

11. Connelly, P., \& Rosen, S. (2006). Treatment for HIV/AIDS at South Africa's largest employers: myth and reality. South African Medical Journal, 96(2), 128-133. Retrieved from https://www.ncbi.nlm.nih. gov/pubmed/16532081

12. Coppa, M., \& Sriramesh, K. (2013). Corporate social responsibility among SMEs in Italy. Public Relations Review, 39(1), 30-39. https://doi. org/10.1016/j.pubrev.2012.09.009

13. Davids, A., Weihs, M., Tunzi, A., \& Tassiopoulos, D. (2017). What works in HIV and AIDS and the world of work in the South African and Namibian tourism industry at selected country sites: country report: South Africa.

14. Deane, K., Stevano, S., \& Johnston, D. (2018). Employers' responses to the HIV epidemic in sub-Saharan Africa: Revisiting the evidence. Development Policy Review, 37(2), 245-259. https://doi.org/10.1111/ dpr. 12380

15. Demuijnck, G., \& Ngnodjom, H. (2013). Responsibility and informal CSR in formal Cameroonian SMEs. Journal of business ethics, 112(4), 653-665. Retrieved from https://link. springer.com/article/10.1007/ s10551-012-1564-3

16. Dickinson, D. (2004). Corporate South Africa's response to HIV/ AIDS: Why so slow? Journal of Southern African Studies, 30(3),
627-650. https://doi.org/10.1080/0 305707042000254137

17. Dickinson, D. (2004, June). Medium-sized companies, many stakeholders: The sociology, psychology and political economy of HIV/AIDS responses in three manufacturing companies. Paper presented at HIV/AIDS in the Workplace Research Symposium, University of Witwatersrand (pp. 35-47).

18. Douglas, R., \& Sutherland, M. (2009). An organisational change model for successful HIV/ AIDS workplace interventions. South African Journal of Labour Relations, 33(2), 54-74. Retrieved from https://repository.up.ac.za/ bitstream/handle/2263/13727/ Douglas_Organisational\%282009\%29.pdf? sequence $=1$

19. Duarte, K., \& Houlihan, M. (2010). A rose by any other name? Innovative CSR: From Risk Management to Value Creation.

20. Enslin, L. (2007). Managing HIV/AIDS in Small and Medium Enterprises (SMEs), with the focus on South Africa: An experience by the International Finance Corporation (IFC), the private sector division of the World Bank Grou (Masters dissertation). Stellenbosch: Stellenbosch University.

21. Fassin, Y. (2008). SMEs and the fallacy of formalising CSR. Business ethics: a european review, 17(4), 364-378. https:// doi.org/10.1111/j.14678608.2008.00540.x

22. Fleshman, M. (2006). Progress in Zimbabwes HIV/AIDS battle. Africa Renewal, 19(4). Retrieved from https://www.un.org/africarenewal/magazine/january-2006/ progress-zimbabwe $\%$ E2\%80\%99shivaids-battle

23. Gellert, F., \& de Graaf, F. (2012). Corporate social responsibility and aging workforces: an explorative study of corporate social responsibility implementation in small-and medium-sized enterprises. Business Ethics: A European Review, 21(4), 353-363. https://doi.org/10.1111/j.14678608.2012.01659.x
24. George, G., \& Quinlan, T. (2009). 'Health management' in the private sector in the context of HIV/ AIDS: progress and challenges faced by company programmes in South Africa. Sustainable Development, 17(1), 19-29. https:// doi.org/10.1002/sd.366

25. GIZ (2013). Shaping Corporate Social Responsibility in subSaharan Africa Guidance Notes from a Mapping Survey (Deutsche Gesellschaft für Internationale Zusammenarbeit).

26. HIV/AIDS, S. A. B. C. O. (2004). The Economic Impact of HIV/AIDS on Business in South Africa 2003. Stellenbosch, South Africa: Bureau of Economic Research.

27. International Labour Organisation and Ministry of Small and Medium Enterprises Development (2006). The impact of HIV/AIDS on the SME sector in Zimbabwe (ILO Sub-Regional Office for Southern Africa).

28. International Labour Organization (2007). Helping micro and small enterprises cope with HIV/AIDS: A handbook for small business associations. Geneva: International Labour Office.

29. Jamali, D., Zanhour, M., \& Keshishian, T. (2009). Peculiar strengths and relational attributes of SMEs in the context of CSR. Journal of Business Ethics, 87(3), 355-377. Retrieved from https:// link.springer.com/article/10.1007/ s10551-008-9925-7

30. Jenkins, H. (2006). Small business champions for corporate social responsibility. Journal of Business Ethics, 67(3), 241-256. Retrieved from https://link.springer.com/ article/10.1007/s10551-006-9182-6

31. Kaniki, T. (2003). Perceptions of Employers about HIV/AIDS in Micro and Small Enterprises Employing Women Workers A Case Study of Harare (Gender Issues Research Report Series - No. 19). Organization for Social Science Research in Eastern and Southern Africa.

32. Kaseke, E. (2009). Workplace initiatives for the management of HIV/AIDS: The experience of 
Zimbabwe. International Journal of Social Security and Workers Compensation, 1(1), 13-19. Retrieved from http://classic. austlii.edu.au/au/journals/IntJlSSWC/2009/2.html

33. Kotler, P., \& Lee, N. (2005). Best of breed: When it comes to gaining a market edge while supporting a social cause,"corporate social marketing" leads the pack. Social marketing quarterly, 11(3-4), 91-103. https://doi.org/10.1080\% 2F15245000500414480

34. Maignan, I., \& Ferrell, O. (2004). Corporate social responsibility and marketing: An integrative framework. Journal of the Academy of Marketing science, 32(1), 3-19. Retrieved from https://link.springer.com/article/10.1177/0092070303258971

35. Makina, D. (2010). Historical perspective on Zimbabwe's economic performance: A tale of five lost decades. Journal of Developing Societies, 26(1), 99-123. https://doi.org/10.1177\%2F016979 6X1002600105

36. Makwara, T. (2015). Employee perceptions towards outsourcing of HIV/AIDS services (Masters dissertation). Stellenbosch Stellenbosch University.

37. Manuere, F. (2016). Corporate social responsibility practices in small to medium enterprises in Zimbabwe (Doctoral dissertation University of KwaZulu Natal).

38. Mapungwana, P. (2014). An investigation into young women workers' experiences of the HIV and AIDS response of small and medium sized enterprises in a semi urban area in KwaZulu-Natal. University of South Africa.

39. McWilliams, A., Siegel, D., \& Wright, P. (2006). Corporate social responsibility: International perspectives. SSRN. Retrieved from https://papers.ssrn.com/sol3/ papers.cfm?abstract_id $=900834$

40. Rambe, P. (2018). Reconciling business social responsibility goals, activities and practices in hospitality SMMES in an emerging economy. African Journal of Business and Economic Research, 13(1), 177-218.

Retrieved from https://journals. co.za/content/journal/10520/EJCeefeeba45

41. Rosen, S., Feeley, F., Connelly, P., \& Simon, J. (2007). The private sector and HIV/AIDS in Africa: taking stock of 6 years of applied research. Aids, 21, S41-S51. https://doi.org/10.1097/01. aids.0000279693.61652.2d

42. Roy, A., Vyas, V., \& Jain, P. (2013). SMEs Motivation: Corporate Social Responsibility. SCMS Journal of Indian Management, 10(1).

43. Simbayi, L. (2007). The impact of and responses to HIV/AIDS in the private security and legal services industry in South Africa.

44. Small Enterprise Development Agency (2016). ANNUAL REPORT 2015/2016.

45. Steenkamp, L., Von der Marwitz, J., Baasner-Weihs, F., \& Pietersen, J. (2015). Should HIV and AIDS workplace programmes still be advocated in the automotive industry? SA Journal of Human Resource Managemen, 13(1), 10. Retrieved from https://sajhrm. co.za/index.php/sajhrm/article/ view/609

46. Taghian, M., D'Souza, C., \& Polonsky, M. (2015). A stakeholder approach to corporate social responsibility, reputation and business performance. Social Responsibility Journal, 11(2), 340363. https://doi.org/10.1108/SRJ06-2012-0068

47. Tanga, P., Gutura, P., \& Shava, G. (2016). Management of HIV/AIDS Programmes at the Workplace: A Case Study of Selected Organizations in Chris Hani District, Eastern Cape Province, South Africa. Journal of Human Ecology, 55(3), 227-236. https://doi.org/10.1080/09709274. 2016.11907028

48. Tustin, D. (2015). The physiognomy of SMMEs in South Africa and consequential national strategy reinforcement. The Retail and Marketing Review, 11(1), 77-91. Retrieved from https:// journals.co.za/content/irmr1/11/1/ EJC177068?TRACK=RSS

49. Vinga, A. (2017). HIV, Aids chokes informal sector. Retrieved from https://nehandaradio. com/2017/04/27/hiv-aids-chokesinformal-sector/ (accessed on January 23, 2019).

50. Wilkins, N. (1999). HIV/AIDS and the informal sector. AIDS analysis Africa, 10(1), 7-10. Retrieved from https://www.ncbi. nlm.nih.gov/pubmed/12295125 